СТАН ТА РОЗВИТОК ДЕРЖАВНОї ФIHАНСОВОї ПІДТРИМКИ АГРАРНОГО СЕКТОРУ УКРАЇНИ

СТАН ТА РОЗВИТОК
ДЕРЖАВНӦ̈
ФІНАНСОВӦ̈
ПІДТРИМКИ
АГРАРНОГО СЕКТОРУ
УКРАЇНИ

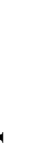

(a)

\begin{abstract}
У статті проаналізовано напрями та обсяги державної фінансової підтримки аграрного сектору України. Актуальність проблеми зумовлена внесенням доповнення до Постанови Кабінету Міністрів України «Про затвердження Порядку використання коштів, передбачених у державному бюджеті для фінансової підтримки сільгосптоваровиробників» від 08.02.2017 р. № 77 Постановою від 07.04.2021 p. № 315 та відповідним розширенням сфери державної підтримки за напрямами: розвиток тваринництва та переробка сільськогосподарської продукиії; фінансова підтримка розвитку фермерських господарств; часткова компенсація вартості сільськогосподарської техніки та обладнання вітчизняного виробництва; фінансова підтримка заходів в агропромисловому комплексі иляхом здешевлення кредитів; фінансова підтримка розвитку садівництва, виноградарства та хмелярства; надання сімейним фермерським господарствам додаткової фрінансової підтримки через механізм доплати на користь застрахованих осіб - членів/голови сімейного фермерського господарства єдиного внеску на загальнообов'язкове державне сочіальне страхування.
\end{abstract}

Досліджено особливості механізму державної підтримки аграрного сектору в частині функиіональних та програмних видатків, фінансування програм за період 20172020 рр. та його загальну ефективність. Розкрито стан виконання програм кредитних субсидій, підтримки фермерства, часткового фінансування придбання техніки за регіонами. За результатами кореляційного аналізу описано тісноту зв'язку між бюджетними програмами та станом аграрної економіки у частині, на яку спрямовані видатки Державного бюджету України. Уточнено підходи до перерозподілу ВВП через бюджет, за даними аналізу вкладу галузі та отриманого фінансування.

На підставі здійснених досліджень щзодо удосконалення механізму державної підтримки запропоновано парадигму державного фінансування аграрного сектору як науково-методичний підхід, який дозволяє скорегувати існуючий механізм дотацій, очінити 
ефективність напрямів підтримки, удосконалити моніторинг та визначити точки контролю за використанням бюджетних коштів. Одержані дані можуть бути використані при формуванні бюджетних регіональних запитів та формування стратегї сталого розвитку сільських регіонів.

Ключові слова: аграрний сектор, державне регулювання, фінансова підтримка, бюджет, дотації, підтримка, програми.

Табл.: 4. Рис.: 2. Літ.: 25

\title{
STATE AND DEVELOPMENT OF STATE FINANCIAL SUPPORT OF THE AGRICULTURAL SECTOR OF UKRAINE
}

\author{
KOVAL Natalia, \\ Candidate of Economic Sciences, \\ Associate Professor of the Department of Account and Taxation \\ in the Fields of the Economy, \\ Vinnytsia National Agrarian University \\ (Vinnytsia) \\ RADCHENKO Oksana, \\ Candidate of Economic Sciences, \\ Leading Researcher of Financial, Credit and Tax Policy Department, \\ NSC «Institute of Agrarian Economics» \\ (Kyiv) \\ ISHCHENKO Yana, \\ Candidate of Economic Sciences, \\ Associate Professor of the Departments of Account and Taxation \\ in the Fields of the Economy, \\ Vinnytsia National Agrarian University
} (Vinnytsia)

The article analyses the directions and volumes of state financial support for the agricultural sector of Ukraine. The urgency of the problem is caused by the addition of the Cabinet of Minister's of Ukraine Resolution "On approval of the Procedure for using funds provided in the state budget for financial support of agricultural producers» daed 08.02.2017 № 77 by Resolution dated 07.04.2021 № 315 and the corresponding expansion of state support, namely: development of stock-raising and processing of agricultural produce; financial support of development of farms; partial indemnification of cost of agricultural technique and equipment of home production; financial support of measures in an agroindustrial complex by reduction of prices of credits; financial support of development of gardening, viticulture and hopgrowing; grant to the domestic farms of additional financial support through the mechanism of additional charge in behalf on the insured persons - members/chairman of domestic farm of single payment on obligatory state social.

The peculiarities of the state support mechanism for the agrarian sector have been researched in the part of functional and programmatic charges, financing of the programmes for period 2017-2020 and its general efficiency. The state of implementation of programmes of credit subsidies, support of farming, partial financing of purchase of equipment by regions has been revealed. According to the results of the correlation analysis, the closeness of the connection between the budget programs and the state of the agrarian economy in the part to which the expenditures of the State Budget of Ukraine are directed is described. Approaches to the 
redistribution of GDP through the budget have been clarified, according to the analysis of the industry's contribution and the received funding.

Based on the research for improving the mechanism of state support, the paradigm of state funding of the agricultural sector has been proposed as a scientific and methodological approach that allows to adjust the existing mechanism of subsidies, assess the effectiveness of support, improve monitoring and identify control points for budget use. The obtained data can be used while forming budgetary regional requests and forming the strategy for sustainable development of rural areas.

Key words: agrarian sector, government regulation, financial support, budget, grants, support, programmes.

Tabl.: 4. Fig.: 2. Lit.: 25.

\title{
СОСТОЯНИЕ И РАЗВИТИЕ ГОСУДАРСТВЕННОЙ ФИНАНСОВОЙ ПОДДЕРЖКИ АГРАРНОГО СЕКТОРА УКРАИНЫ
}

\author{
КОВАЛЬ Н.И., \\ кандидат экономических наук, \\ доцент кафедры учета и налогообложения в отраслях экономики, \\ Винницкий национальный аграрный университет \\ (2. Винница) \\ РАДЧЕНКО О.Д., \\ кандидат экономических наук, \\ ведущий научный сотрудник отдела финансово-кредитной и \\ налоговой политики, \\ ННЦ «Институт аграрной экономики» \\ (2. Киев) \\ ИЩЕНКО Я.П., \\ кандидат экономических наук, \\ доцент кафедры учета и налогообложения в отраслях экономики, \\ Винницкий национальный аграрный университет
} (2. Винница)

В статье проанализированы направления и объемь государственной финансовой поддержки аграрного сектора Украины. Актуальность проблемы обусловлена внесением дополнения в Постановления Кабинета Министров Украины «Об утверждении Порядка использования средств, предусмотренных в государственном бюджете для финансовой поддержки сельхозтоваропроизводителей» от 08.02.2017 2. № 77 Постановлением от 07.04 .2021 2. № 315 и соответствующего расширения направлений государственной поддержки по направлениям: развитие животноводства и переработки сельскохозяйственной продукиии; финансовая поддержка развития фермерских хозяйств; частичная компенсачия стоимости сельскохозяйственной техники и оборудования отечественного производства; финансовая поддержка мероприятий в агропромылиенном комплексе путем удешевления кредитов; финансовая поддержка развития садоводства, виноградарства и хмелеводства; предоставление семейным фермерским хозяйствам дополнительной финансовой поддержки через механизм доплать в пользу застрахованных лии - членов / председателя семейного фермерского хозяйства единого взноса на общеобязательное государственное сочиальное страхование. 
Исследовань особенности механизма государственной поддержки аграрного сектора в части функциональных и программных расходов, финансирования программ за период 2017-2020 г2. и его общую эффективность. Раскрыто состояние выполнения программ кредитных субсидий, поддержки фермерства, частичного финансирования приобретения техники за регионами. По результатам корреляиионного анализа описана теснота связи между бюджетными программами и состоянием аграрной экономики в части, на которую направленные расходы Государственного бюджета. Уточнены подходы $\kappa$ перераспределению ВВП через бюджет по данным анализа вклада отрасли и полученного.

На основании осуществленных исследований относительно усовершенствования механизма государственной поддержки предложена парадигма государственного финансирования аграрного сектора как научно-методический подход, который позволяет скорректировать существующий механизм дотаций, оценивать эффективность направлений поддержки, усовершенствовать мониторинг и определить точки контроля за использованием бюджетных средств. Полученные данные могут быть использованы при формировании бюджетных региональных запросов и создании стратегии устойчивого развития сельских регионов.

Ключевые слова: аграрный сектор, государственное регулирование, финансовая поддержка, бюджет, дотации, программы.

Табл.: 4. Рис.: 2. Лит.: 25

Постановка проблеми. Аграрний сектор у сучасних умовах є однією iз найбільш важливих галузей вітчизняної економіки. Станом на теперішній час, він займає 70\% земель, продукує понад 40\% експорту, формує 10\% ВВП, 20\% чистого прибутку, 9,5\% капітальних інвестицій, $є$ джерелом зайнятості 7\% працюючих i гарантом продовольчої безпеки [7]. Внаслідок підвищеної чутливості до впливу різного роду негативних чинників, він потребує державної підтримки, яка є засобом регулювання розвитку аграрної галузі та фінансування окремих напрямів діяльності, інфраструктури, форм господарювання і проявляється, насамперед, у фінансовій підтримці. Крім потреби захисту аграрної галузі від внутрішньосистемних ризиків та підвищення ii конкурентоспроможності, підтримка необхідна ще й як засіб державного протекціонізму, оскільки Україна, як аграрна держава, є учасником міжнародних ринків, за багатьма товарними позиціями утримує лідерство.

Механізм державної фінансової підтримки сформувався на основі законодавства та регулюється Законами України «Про державну підтримку сільського господарства України», «Про державний бюджет України», галузевими стратегіями та концепціями, а порядок витрачання бюджетних коштів визначається Постановами Кабінету Міністрів України, зокрема «Про затвердження Порядку використання коштів, передбачених у державному бюджеті для фінансової підтримки сільгосптоваровиробників» від 08.02.2017 р. № 77 [17], до якої окремою постановою від 07.04.2021 р. № 315 [18] внесені доповнення напрямів державної підтримки, що зумовлює актуальність наукового дослідження даної теми.

Аналіз останніх досліджень і публікацій. Наукові дослідження державного регулювання аграрного сектору, фінансової підтримки та іiі інформаційного забезпечення висвітлені у працях: I. Гончарук [3], М. Дем'яненка [5], А. Діброви [6], В. Жука [16], Н. Здирко [4], Т. Калашнікової [8], Г. Калетніка [9; 10], С. Кваші [14], П. Саблука [5], 
Л. Тулуша [20] та інших вчених.

Важливим аспектом $\epsilon$ також інформаційне забезпечення процесу одержання бюджетних коштів, для зворотного зв'язку та для контролю за їх ефективністю, чому присвячені праці В. Метелиці [16, с. 127], Т. Мулик [22], Н. Правдюк [1;22] та інших.

Загалом дослідниками визначено, що основними проблемами державної підтримки аграрного сектору України є: відсутність науково обгрунтованої стратегії розвитку галузі та ії управління; постійне недофінансування програми бюджетної підтримки; недостатній рівень впливу заходів бюджетної підтримки на розвиток сільського господарства; непоінформованість та неповна довіра до держави 3 боку сільгоспвиробників тощо. Тому формування парадигми державної фінансової підтримки розвитку аграрного сектору України $\epsilon$ актуальною науковою проблемою.

Формулювання цілей статті. Мета дослідження - розкрити стан державної підтримки як обумовлену парадигму, що регулює сталий розвиток аграрного сектору України з врахуванням інституційних змін законодавчого

IV, підтримка аграрної галузі здійснюється за напрямами, які гарантують продовольчу безпеку та сталий розвиток. Також, головні завдання 10-річного «Європейського плану для України» [24] - розбудова сприятливого інвестиційного середовища та підтримка економічного зростання, де серед попередньо визначених аграрних компонентів реалізації проєкту вказано умови: гармонізація українського законодавства до вимог $\mathrm{CC}$, удосконалення системи державної підтримки сільського господарства, стимулювання диверсифікації виробництва аграрного сектору, розвиток сільських територій, посилення спроможності у сфері безпеки харчових продуктів, вирішення логістичних питань, поліпшення якості землекористування, покращення управління водними ресурсами, покращення доступу до сільськогосподарських ресурсів, удосконалення доступу до фінансових ресурсів та інструментів управління ризиками.

Постанова Кабінету Міністрів України від 8 лютого 2017 р. № 77 «Про порядок використання коштів, передбачених у державному бюджеті для фінансової підтримки сільгосптоваровиробників» визначає механізм використання коштів, передбачених у державному бюджеті [17]. Ціллю використання бюджетних коштів $\epsilon$ збільшення обсягів виробництва сільськогосподарської продукції, підвищення продуктивності в сільському господарстві, сприяння розвитку аграрного ринку та забезпечення продовольчої 
безпеки.

У квітні 2021 року до існуючого переліку Постановою № 315 додали напрями: державну підтримку страхування сільськогосподарської продукції; відшкодовування втрат від пошкодження посівів сільськогосподарських культур внаслідок надзвичайних ситуацій техногенного та природного характеру; державну підтримку сільськогосподарських товаровиробників, які використовують меліоровані землі; виробників органічної сільськогосподарської продукції; виробників картоплі; сільськогосподарських товаровиробників шляхом виділення бюджетних субсидій iз розрахунку на одиницю оброблюваних угідь [18].

До 2020 року щодо механізму державної фінансової підтримки сформувалась наукова парадигма, яка в тій чи іншій мірі окреслювала кредитування витрат аграрного сектору; субсидії на придбання ресурсів та технічне переоснащення; цінове регулювання аграрного ринку; підтримку окремих форм господарювання.

Фактично державна фінансова підтримка аграрного сектору за підсумками 2017-2020 років та проєктом бюджету на 2021 рік представлена державними програмами здешевлення кредитів, підтримки тваринництва, фінансуванням фермерських господарств, підтримкою садівництва, фінансовою підтримкою сільськогосподарських товаровиробників, у якій передбачено структуру програм підтримки забезпечення ресурсами, насамперед засобами виробництва (табл. 1).

Табличя 1

Фінансування бюджетних аграрних програм в Україні у 2017-2021 рр., млрд грн

\begin{tabular}{|c|c|c|c|c|c|c|c|c|c|c|}
\hline \multirow{3}{*}{ Програми } & \multicolumn{9}{|c|}{ Роки } & \multirow{3}{*}{$\begin{array}{c}2021 \mathrm{p} . \\
\text { до } \\
2017 \mathrm{p} . \\
(+/-) \\
\text { план }\end{array}$} \\
\hline & \multicolumn{2}{|c|}{2017} & \multicolumn{2}{|c|}{2018} & \multicolumn{2}{|c|}{2019} & \multicolumn{2}{|c|}{2020} & \multirow{2}{*}{$\begin{array}{c}2021 \\
\text { план }\end{array}$} & \\
\hline & план & факт & план & факт & план & факт & план & факт & & \\
\hline $\begin{array}{l}\text { Здешевлення } \\
\text { кредитів }\end{array}$ & 0,300 & 0,294 & 0,266 & 0,265 & 0,451 & 0,449 & 1,200 & 1,050 & 1,200 & 0,900 \\
\hline $\begin{array}{l}\text { Фінансова } \\
\text { підтримка }\end{array}$ & 4,550 & 4,134 & 0,955 & 0,695 & 0,682 & 0,64 & 1,000 & 0,986 & 1,000 & $-3,550$ \\
\hline $\begin{array}{l}\text { Підтримка } \\
\text { фермерів }\end{array}$ & - & - & 0,210 & 0,048 & 0,465 & 0,416 & 0,400 & 0,032 & 0,210 & 0,210 \\
\hline $\begin{array}{l}\text { Підтримка } \\
\text { тваринництва }\end{array}$ & 0,170 & 0,166 & 2,401 & 2,393 & 2,930 & 2,432 & 1,000 & 1,039 & 1,150 & 0,980 \\
\hline $\begin{array}{l}\text { Підтримка } \\
\text { садівництва }\end{array}$ & 0,299 & 0,299 & 0,400 & 0,397 & 0,400 & 0,398 & 0,400 & 0,290 & 0,450 & 0,221 \\
\hline Інші заходи & 0,249 & 0,187 & 0,194 & 0,435 & 0,053 & 0,153 & 0,267 & 0,563 & 0,490 & 0,241 \\
\hline $\begin{array}{l}\text { Всього } \\
\text { видатків }\end{array}$ & 5,568 & 5,080 & 4,426 & 4,233 & 4,981 & 4,488 & 4,267 & 3,960 & 4,500 & $-1,068$ \\
\hline
\end{tabular}

Джерело: сформовано авторами за даними [25]

За період 2017-2020 pp. фактична державна підтримка галузі склала 17,761 млрд грн. За приведеними даними, у структурі видатків на базі фактичного фінансування за 2020 рік лідирують програми здешевлення кредитування - 26,5\%, підтримки галузі тваринництва - 26\% та фінансова 
підтримка виробників (здешевлення придбання вітчизняної техніки) - 25\%, далі йдуть підтримка фермерів, садівництва та інші програми.

Ефективність програм за бюджетним критерієм частки видатків на галузь у загальному фінансуванні приведена на рис. 1.

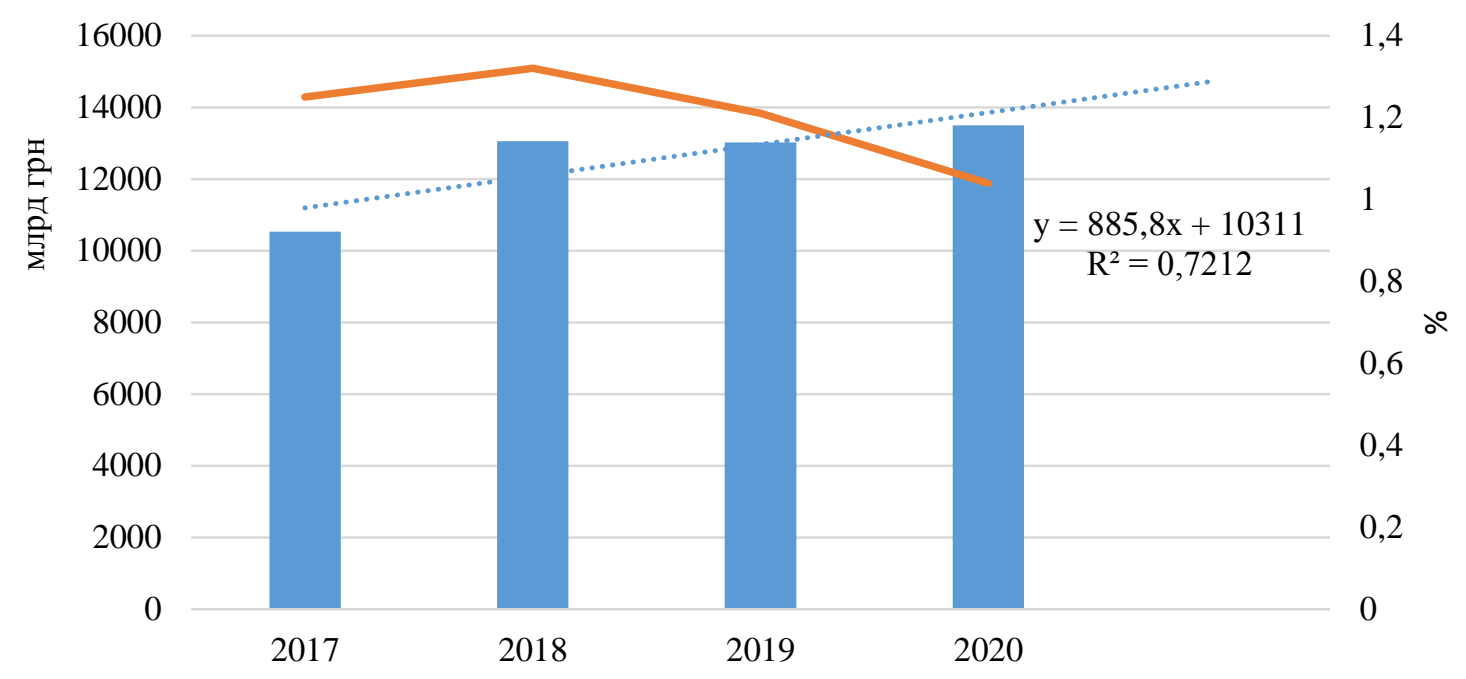

Видатки бюджету на агросектор

— Частка агросектору у видатках бюджету

Puc. 1. Динаміка функціональних видатків на аграрний сектор та їх частка у Державному бюджеті України у 2017-2020 рр., млрд грн Джерело: сформовано авторами за даними [25]

Кореляційний аналіз динаміки видатків держбюджету на агросектор свідчить про значний потенціал зростання, оскільки R2 становить $72 \%$. Крім того, ефективність фінансування за часткою у структурі видатків наближається до нормативного, яке було визначено відповідно до змін, прийнятих при затвердженні Державного бюджету 2017 року, коли у Бюджетному Кодексі (Розділ VI п. 42) [2] було передбачено, що у 2017-2021 роках щорічний обсяг коштів Державного бюджету України, які спрямовуються на державну підтримку сільськогосподарських товаровиробників, має становити не менше $1 \%$ випуску продукції у сільському господарстві, і за основу розрахунків на 2017 рік використано дані 2015 року та затверджено 5,5 млрд грн.

Регіональне представлення розподілу коштів за найбільш об'ємною програмою державної підтримки здешевлення кредитування наведено в табл. 2 [7].

Станом на кінець 2020 року за даними Інформаційно-аналітичного порталу АПК України [7] загальний обсяг кредитів, залучених підприємствами, склав 143,56 млрд грн, із них пільгових (що підлягають компенсації) 24,8 млрд грн, які залучили 4231 підприємство, у тому числі: за видами кредитів: короткострокових - 11,6 млрд грн $(46,7 \%)$; середньострокових 6,1 млрд грн $(24,7 \%)$; довгострокових - 7,1 млрд грн $(28,6 \%)$; на галузь тваринництва - 4,5 млрд грн (18\%); інші галузі - 20,3 млрд грн (82\%).

Найбільше компенсовано кредитів у Одеській (91,6 млн грн), Харківській (71,0 млн грн), Тернопільській (68,9 млн грн), Вінницькій (66,5 млн грн) та Черкаській $(65,4$ млн грн) областях. Середні процентні ставки банків, в яких 
суб’єкти господарювання залучили кредити, становили 18-22\% річних.

Таблиия 2

Стан фінансової підтримки за напрямом здешевлення кредитування аграрних підприсмств в Україні у 2017 та 2020 рр., млн грн

\begin{tabular}{|c|c|c|c|c|c|c|c|}
\hline \multirow[b]{2}{*}{ Область } & \multicolumn{3}{|c|}{2017 p. } & \multicolumn{3}{|c|}{2020 p. } & \multirow{2}{*}{$\begin{array}{c}\text { Відхилення } \\
\text { результатів } \\
\text { фінансування } \\
(+/-) \\
\end{array}$} \\
\hline & $\begin{array}{l}\text { к-ть. } \\
\text { під-в }\end{array}$ & $\begin{array}{l}\text { залучені } \\
\text { кредити }\end{array}$ & фінансування & $\begin{array}{l}\text { к-ть. } \\
\text { під-в }\end{array}$ & $\begin{array}{l}\text { залучені } \\
\text { кредити }\end{array}$ & фінансування & \\
\hline Вінницька & 47 & 270544,05 & 10389,02 & 377 & 3354938,2 & 66462,2 & 56073,18 \\
\hline Волинська & 29 & 434700,71 & 18521,70 & 102 & 2719444,2 & 31286,7 & 12,765 \\
\hline Дніпропетровська & 3 & 542708,27 & 8219,36 & 271 & 9890210,1 & 48141,8 & 39922,44 \\
\hline Донецька & 14 & 42510,21 & 2435,61 & 116 & 622615,9 & 30330,2 & 27894,59 \\
\hline Житомирська & 30 & 293478,00 & 6978,50 & 104 & 2643912,2 & 17985,7 & 11007,20 \\
\hline Закарпатська & 3 & 3760,00 & 321,33 & 8 & 427373,3 & 1440,3 & 1118,97 \\
\hline Запорізька & 30 & 216635,82 & 12412,22 & 262 & 8389861,3 & 48008,1 & 35595,88 \\
\hline Івано-Франківська & 18 & 192881,68 & 9474,07 & 44 & 1782464,2 & 18140,9 & 8666,83 \\
\hline Київська & 34 & 1167888,01 & 19954,86 & 108 & 7878037,1 & 45948,6 & 25993,74 \\
\hline Кіровоградська & 24 & 327097,97 & 7860,65 & 381 & 7639338,4 & 46636,0 & 38775,35 \\
\hline Луганська & 21 & 88978,85 & 4755,48 & 132 & 665382,0 & 21450,3 & 16694,82 \\
\hline Львівська & 23 & 98685,43 & 6313,98 & 110 & 858552,1 & 39730,3 & 33416,32 \\
\hline Миколаївська & 60 & 214964,81 & 7722,07 & 238 & 5118514,7 & 44158,6 & 36436,53 \\
\hline Одеська & 34 & 233931,61 & 8292,15 & 312 & 2816209,8 & 91612,3 & 83320,15 \\
\hline Полтавська & 28 & 246899,00 & 20548,57 & 346 & 17606289,3 & 64068,7 & 43520,2 \\
\hline Рівненська & 21 & 214305,70 & 9147,19 & 63 & 1247208,4 & 27490,3 & 18343,11 \\
\hline Сумська & 62 & 294826,19 & 9431,11 & 157 & 3318636,2 & 51270,9 & 41839,79 \\
\hline Тернопільська & 35 & 673471,00 & 28639,46 & 138 & 10771825,8 & 68912,6 & 40273,14 \\
\hline Харківська & 36 & 1196605,59 & 10060,36 & 218 & 8218376,5 & 70981,9 & 60921,54 \\
\hline Херсонська & 32 & 224295,34 & 5761,90 & 165 & 2609111,8 & 52432,1 & 46670,2 \\
\hline Хмельницька & 38 & 678321,93 & 24760,61 & 182 & 11571998,5 & 51912,6 & 27151,99 \\
\hline Черкаська & 49 & 848468,32 & 19282,73 & 233 & 26061202,0 & 65392,7 & 46109,97 \\
\hline Чернівецька & 8 & 327715,60 & 6764,73 & 36 & 4658874,0 & 11569,4 & 4804,67 \\
\hline Чернігівська & 40 & 334802,06 & 7865,29 & 128 & 2693052,6 & 32334,3 & 31246,901 \\
\hline Всього & 719 & 9168476,15 & 265912,95 & 4231 & 143563428,5 & 1047697,5 & 781784,55 \\
\hline
\end{tabular}

Джерело: складено авторами за даними [7]

Оцінка ефективності застосування механізму здешевлення кредитів висвітлює ряд недоліків: недосконалість вибору і відбору об'єктів часткової компенсації та порядку розрахунку розміру компенсаційної ставки; організаційна i технічна складність механізму кредитних субсидій, його поширення на різних позичальників та напрямки кредитування; незначна частка позичальників, яким передбачені особливі умови (граничний обсяг реалізації, перевага галузі тваринництва); розбіжність статистики по загальних кредитах за даними Національного банку України та Міністерства аграрної політики та продовольства України; нестабільний характер планування i виділення коштів із держбюджету на ці цілі, щорічне уточнення Порядку надання пільгових кредитів, незначні обсяги виділених бюджетних коштів, однобічний показник бази розподілу ресурсів за регіонами тощо [20, с. 88; 22, c. 185].

Існуючі ірраціональні підходи до розподілу бюджетної підтримки аграрного сектору економіки стримують параметри нарощування його потенціалу, які формалізуються у наступному: пріоритетність під час виділення бюджетних коштів здебільшого надається потужним виробникам, які лобіюють можливість їх отримання на найвищих ланках управління органів державної 
влади; занадто бюрократизований процес отримання бюджетної фінансової підтримки, що супроводжується оформленням надмірної кількості документів і процедурних моментів; бюджетні кошти, як правило, спрямовуються на поповнення обігових коштів або ж на задоволення споживчих потреб суб'єктів господарювання в аграрному секторі [11, с. 106].

Відповідно до нововведень напрямів фінансової підтримки, програма «Виплата субсидій на одиницю оброблюваних угідь (1 гектар) фермерським господарствам» фінансується відповідно до Порядку використання коштів, передбачених у державному бюджеті для надання фінансової підтримки фермерським господарствам, затвердженого постановою Кабінету Міністрів України від 07.02.2018 р. № 106 [19]. За 2020 рік Українським державним фондом підтримки фермерських господарств, за його офіційними даними, було виплачено 60,421 млн грн відповідно до 1537 отриманих заявок від фермерів (табл. 3) [7].

Табличяя 3

Стан виконання програми «Надання субсидій фермерським господарствам на одиницю оброблюваних угідь (1 гектар)» в Україні у 2020 р.

\begin{tabular}{|c|c|c|c|c|c|c|}
\hline \multirow{2}{*}{ Область } & \multicolumn{2}{|c|}{ ФГ крім новостворених } & \multicolumn{2}{|c|}{ Новостворені ФГ } & \multicolumn{2}{|c|}{ Разом } \\
\hline & К-ть заяв & Сума, грн & К-ть заяв & Сума, грн & К-ть заяв & Сума, грн \\
\hline Вінницька & 49 & 1464000 & 31 & 1691280 & 80 & 3155280 \\
\hline Волинська & 31 & 832000 & 29 & 1467158 & 60 & 2299158 \\
\hline Дніпропетровська & 37 & 1232000 & 23 & 1379838 & 60 & 2611838 \\
\hline Донецька & 13 & 472000 & 17 & 843000 & 30 & 1315000 \\
\hline Житомирська & 12 & 292000 & 24 & 1325100 & 36 & 1617100 \\
\hline Закарпатська & 18 & 560000 & 7 & 269248 & 25 & 829248 \\
\hline Запорізька & 33 & 884000 & 11 & 660000 & 44 & 1544000 \\
\hline Івано-Франківська & 24 & 708000 & 23 & 772740 & 47 & 1480740 \\
\hline Київська & 12 & 412000 & 16 & 872689 & 28 & 1284689 \\
\hline Кіровоградська & 27 & 720000 & 22 & 1101866 & 49 & 1821866 \\
\hline Луганська & 1 & 12000 & 9 & 388176 & 10 & 400176 \\
\hline Львівська & 41 & 1228000 & 31 & 1541067 & 72 & 2769067 \\
\hline Миколаївська & 159 & 4972000 & 57 & 3018638 & 216 & 7990638 \\
\hline Одеська & 79 & 2184000 & 56 & 3179400 & 135 & 5363400 \\
\hline Полтавська & 55 & 1872000 & 47 & 2705760 & 102 & 4577760 \\
\hline Рівненська & 31 & 796000 & 20 & 867933 & 51 & 1663933 \\
\hline Сумська & 25 & 632000 & 26 & 1477077 & 51 & 2109077 \\
\hline Тернопільська & 12 & 440000 & 10 & 510261 & 22 & 950261 \\
\hline Харківська & 67 & 2036000 & 23 & 1323000 & 90 & 3359000 \\
\hline Херсонська & 83 & 2720000 & 35 & 1963403 & 118 & 4683403 \\
\hline Хмельницька & 52 & 1600000 & 33 & 1616052 & 85 & 3216052 \\
\hline Черкаська & 36 & 1084000 & 33 & 1846664 & 69 & 2930664 \\
\hline Чернівецька & 3 & 96000 & 9 & 429590 & 12 & 525590 \\
\hline Чернігівська & 24 & 696000 & 21 & 1237088 & 45 & 1933088 \\
\hline Разом & 924 & 27944000 & 613 & 32487028 & 1537 & 60431028 \\
\hline
\end{tabular}

Джерело: складено авторами за даними [7]

Регіональний зріз фінансової підтримки на одне фермерське господарство у 2020 році приведений на рис. 2. Новостворені фермерські господарства отримували вищий рівень підтримки, в середньому на господарство до 30 тис. грн, тоді як загальні виплати не перевищували 45 тис. грн на одне господарство. Високий рівень підтримки мали господарства Чернігівської, 
Дніпропетровської, Запорізької областей, низький - Рівненської та ІваноФранківської.

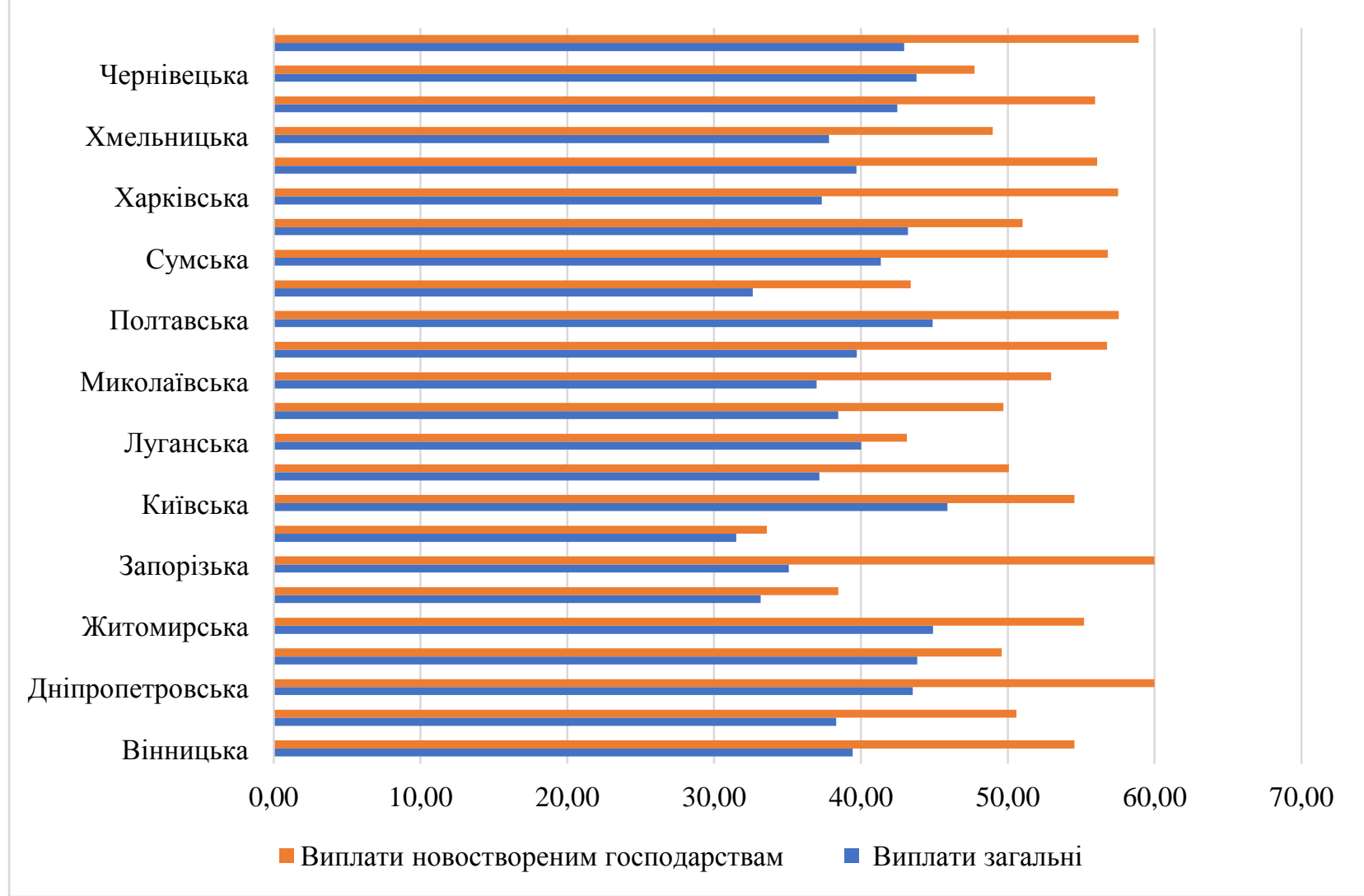

\section{Рис. 2. Регіональний зріз фінансової підтримки на одне фермерське господарство в Україні у 2020 р., тис. грн \\ Джерело: сформовано авторами за даними [7]}

За бюджетною програмою «Фінансова підтримка сільгосптоваровиробників» у 2020 році передбачено видатки на суму 1457,6 млн грн, із них виплачено за жовтень-листопад 2019 року 565 млн грн. Перераховано банкам на суму 421,2 млн грн (за грудень 2019 р. та січеньвересень 2020 р.). Регіональний зріз виконання цієї бюджетної програми приведений у табл. 4 [7].

Регіональний зріз вартості техніки та отриманої компенсації на одну заявку у 2020 році свідчить, що лідерами по видатках програми $є$ Чернігівська, Сумська i Житомирська області. Стан фінансування за бюджетними програмами 2020 року здійснений у рамках плану. Затримки 3 виплатами коштів мали суб' єктивні причини, пов'язані з пандемією, дефіцитом бюджету в окремі місяці.

Новації державної фінансової підтримки аграрного сектору України були означені на засіданні Комітету Верховної Ради України з питань аграрної та земельної політики 17.09.2020 р., де було презентовано пропозиції Міністерства аграрної політики та продовольства України щодо державної підтримки аграрної галузі на 2021-2023 роки.

Стратегія передбачає доповнення підтримки новими та розширення напрямів за чинними програмами. Зокрема, планувалось 7 основних програм 
підтримки, які можуть бути реалізовані у бюджеті 2021 року. При цьому ставиться за мету, щоб усі програми державної підтримки генерували позитивний ефект як в аграрній галузі, так і в економіці країни.

Таблиия 4

\section{Стан фінансування за напрямом «Часткова компенсація вартості сільськогосподарської техніки та обладнання вітчизняного виробництва»,} у 2020 р., тис. грн

\begin{tabular}{|l|c|c|c|c|c|}
\hline \multicolumn{1}{|c|}{ Область } & $\begin{array}{c}\text { Кількість } \\
\text { заявок }\end{array}$ & $\begin{array}{c}\text { Кількість } \\
\text { техніки та } \\
\text { обладнання }\end{array}$ & $\begin{array}{c}\text { Вартість } \\
\text { техніки та } \\
\text { обладнання } \\
\text { ПДВ }\end{array}$ & $\begin{array}{c}\text { Вартість } \\
\text { техніки та } \\
\text { обладнання } \\
\text { без ПДВ }\end{array}$ & $\begin{array}{c}\text { Часткова } \\
\text { компенсація } \\
\text { техніки та } \\
\text { обладнання }\end{array}$ \\
\hline Вінницька & 238 & 382 & 100292,6 & 83577,13 & 20894,28 \\
\hline Волинська & 39 & 58 & 18132,05 & 15110,04 & 3777,51 \\
\hline Дніпропетровська & 294 & 427 & 147168,5 & 122640,4 & 30660,11 \\
\hline Донецька & 147 & 273 & 68629,38 & 57191,15 & 14297,79 \\
\hline Житомирська & 74 & 133 & 89606,89 & 74672,41 & 18668,1 \\
\hline Закарпатська & 11 & 28 & 8229,797 & 6858,164 & 1714,541 \\
\hline Запорізька & 308 & 480 & 158854,8 & 132379 & 33094,75 \\
\hline Івано-Франківська & 23 & 52 & 12668,7 & 10557,25 & 2639,312 \\
\hline Київська & 179 & 362 & 132651,9 & 110543,2 & 27635,8 \\
\hline Кіровоградська & 335 & 516 & 115418,6 & 96182,18 & 24045,54 \\
\hline Луганська & 182 & 318 & 101330,7 & 84442,24 & 21110,56 \\
\hline Львівська & 76 & 378 & 50513,21 & 42094,35 & 10523,59 \\
\hline Миколаївська & 257 & 389 & 125598,2 & 104665,2 & 26166,3 \\
\hline Одеська & 128 & 184 & 70003,07 & 58335,89 & 14583,97 \\
\hline Полтавська & 256 & 542 & 174401 & 145334,1 & 36333,54 \\
\hline Рівненська & 20 & 27 & 8450,91 & 7042,425 & 1760,606 \\
\hline Сумська & 153 & 294 & 148374,2 & 123645,2 & 30911,3 \\
\hline Тернопільська & 86 & 187 & 49957,26 & 41631,05 & 10407,76 \\
\hline Харківська & 220 & 422 & 114047 & 95039,16 & 23759,79 \\
\hline Херсонська & 186 & 1040 & 101986,9 & 84989,11 & 21247,28 \\
\hline Хмельницька & 107 & 174 & 49384,4 & 41153,66 & 10288,42 \\
\hline Черкаська & 150 & 240 & 56832,74 & 47360,62 & 11840,15 \\
\hline Чернівецька & 35 & 48 & 13576,83 & 11314,03 & 2828,506 \\
\hline Чернігівська & 117 & 496 & 105524,8 & 87937,37 & 21984,34 \\
\hline Разом & 3601 & 7447 & 2021635 & 1684695 & 421173,9 \\
\hline
\end{tabular}

Джерело: складено авторами за даними [7]

Профільним Міністерством [7] презентовано нові програми: підтримка розвитку тваринництва та переробки в частині козівництва і вівчарства (дотація 1000 грн), зупинення спаду поголів'я кіз та овець - 50 млн грн; дотація за приріст поголів'я корів власного відтворення (дотація 30 тис. грн), зупинення спаду поголів'я корів - 100 млн грн. Нові програми з бюджетом у 500 млн грн: підтримка страхування сільськогосподарської продукції - 240 млн грн; підтримка зрошення та підтримка органічного виробництва - по 100 млн грн; розвиток картоплярства - 60 млн грн.

На підставі здійснених досліджень можна уточнити стратегію державного фінансування аграрного сектору як науково-методичний підхід, який дозволяє скорегувати існуючий механізм дотацій, оцінювати ефективність напрямів 
підтримки, удосконалити моніторинг та визначити точки контролю за використанням бюджетних коштів.

Висновки. Здійснено оцінку стану державної фінансової підтримки забезпечення аграрного сектору. Встановлено, що за 2017-2020 рр. підтримка галузі склала 17,761 млрд грн, у структурі видатків лідирують програми здешевлення кредитування, підтримки галузі тваринництва та компенсації придбання техніки. Кореляційний аналіз динаміки видатків держбюджету на аграрний сектор свідчить про значний потенціал зростання - не нижче $72 \%,-\mathrm{a}$ ефективність фінансування за часткою у структурі видатків Держбюджету наближається до нормативного 1\%, як це передбачено у Бюджетному Кодексі.

Досліджено програму кредитних субсидій, яка станом на кінець 2020 року дозволила залучити 143,56 млрд грн кредитів, із них 17\% пільгових. Для підтримки фермерства, відповідно до нововведень напрямів фінансової підтримки, розроблена програма виплати субсидій на 1 га, за якою у 2020 році виплачено 60,421 млн грн згідно отриманих заявок. Наведено також бюджет нових програм на 2021 рік відповідно до розширеного нормативноправового поля.

Для забезпечення послідовності і стабільності аграрної політики, покращення інвестиційного клімату в Україні необхідно використовувати практику зарубіжних країн щодо розробки та реалізації масштабних цільових програм.

Подальші дослідження у цій сфері лежать у площині моделювання оптимальних пропорцій фінансової підтримки та напрямів і обсягів бюджетних програм як інструменту стимулювання економічного зростання і збільшення обсягу фінансових ресурсів аграрних підприємств.

\section{Список використаних джерел}

1. Актуальні питання організації обліково-аналітичного процесу на підприємствах агропромислового комплексу України: колективна монографія за ред. Н.Л. Правдюк. Вінниця: ПП Балюк, 2010. 680 с.

2. Бюджетний кодекс України: Закон України від 08.07.2010 № 2456-VI (редакція станом на 01.01.2021). URL: https://zakon.rada.gov.ua/laws/show (дата звернення: 03.04.2021).

3. Гончарук I.В. Формування енергетичної незалежності як основи сталого розвитку агропромислового комплексу. Агросвіт. 2020. № 19-20. С. 38 46.

4. Гуцаленко Л.В., Здирко Н.Г. Обліково-контрольне забезпечення прямої державної підтримки фермерських господарств: монографія. Вінниця: Видавництво ПП «ТД «Едельвейс і К», 2014. 189 с.

5. Державна політика фінансової підтримки розвитку аграрного сектору АПК. Дем’яненко М.Я., Саблук П.Т., Скупий В.М. та ін. Київ : ННЦ IАЕ, 2011. $372 \mathrm{c}$.

6. Діброва А.Д. Державне регулювання сільськогосподарського виробництва: теорія, методологія, практика: монографія. Київ: Формат, 2008. 488 c. 
7. Інформаційно-аналітичний портал АПК України. URL: https://agro.me.gov.ua/ua (дата звернення: 03.04.2021).

8. Калашнікова Т.В. Удосконалення державної підтримки аграрних підприємств України в умовах глобалізації: монографія. Харків: «Влавке», 2014. $280 \mathrm{c}$.

9. Калетнік Г.М., Козяр Н.О. Стратегічні підходи до інвестування аграрного сектору України в сучасних умовах розвитку АПК. Економіка АПК. 2020. № 12 (314). С. 81-89.

10. Калетнік Г.М. Стратегіко-інституційні засади ефективності використання потенціалу аграрного сектору економіки. Економіка, фінанси, менеджмент: актуальні питання науки і практики. 2015. № 1. С. 3-15.

11. Коваль Н.І., Радченко О.Д. Детермінанти стану фінансових ресурсів малих аграрних підприємств. Економіка, фінанси, менеджмент: актуальні питання науки і практики. 2019. № 3. С. 100-116.

12. Коваль Н.І., Радченко О.Д. Облікове забезпечення управління фінансовою діяльністю аграрних підприємств: монографія. Вінниця: монографія. Київ : ННЦ IAE, 2009. 197 с.

15. Міщенко Д.А. Удосконалення системи державної фінансової підтримки сільського господарства України. Агросвіт. 2015. № 18. С. 36-40.

16. Жук В., Герасимук I., Радченко О., Метелиця В. Облік державної підтримки агропромислового виробництва: навч. посіб. За ред. Лузана Ю.Я., Жука В.М., Герасимука І.В. Київ: Юр-Агро-Веста, 2007. 324 с.

17. Про затвердження Порядку використання коштів, передбачених у державному бюджеті для фінансової підтримки сільгосптоваровиробників: постанова КМУ від 08 лютого 2017 p. № 77 . URL: https://zakon.rada.gov.ua/laws/show/130-2017 (дата звернення: 03.04.2021).

18. Про внесення змін до пункту 3 Порядку використання коштів, передбачених у державному бюджеті для фінансової підтримки сільгосптоваровиробників: постанова КМУ від 7 квітня 2021 р. № 315. URL: https://zakon.rada.gov.ua/laws/show/315-2021 (дата звернення: 10.04.2021).

19. Про затвердження Порядку використання коштів, передбачених у державному бюджеті для надання фінансової підтримки розвитку фермерських господарств: постанова КМУ від 7 лютого 2018 р. № 106. URL: https://zakon.rada.gov.ua/laws/show/106-2018 (дата звернення: 09.03.2021).

20. Радченко О.Д., Тулуш Л.Д. Стратегічні напрями бюджетного регулювання розвитку агропромислового виробництва. Економіка АПК. 2012. № 10. C. 81-90.

21. Семенишина Н.В., Радченко О.Д. Інституції сфери обліку бюджетного фінансування сільського господарства. Збірник наукових праџь КНЕУ. 2011. № 1. C. 447-485. 
22. Правдюк Н.Л., Мулик Т.О., Мулик Я.І. Управління фінансовою безпекою підприємств: обліково-аналітичний аспект: монографія. Київ: «Центр учбової літератури», 2018. 224 с.

23. Radchenko O., Tsvihun I., Yasinetska I., Budniak L. Financial resource balance of the agricultural sector: case of Ukraine. Independent Journal of Management \& Production. 2020. Vol. 11, № 8. P. 615-625.

24. European Plan for Ukraine. URL: https://g8fip1kplyr33r3krz5b97d1wpengine.netdna-ssl.com/wp-content/uploads/2017/11/Presentation-EuropeanPlan Ukraineupdate.pdf (дата звернення: 08.04.2021).

25. Дані Державної казначейської служби України. URL: https://www.treasury.gov.ua/ua (дата звернення: 09.04.2021).

\section{References}

1. Pravdiuk, N.L. (Eds.) (2010). Aktualni pytannia orhanizatsii oblikovoanalitychnoho protsesu na pidpryiemstvakh ahropromyslovoho kompleksu Ukrainy [Current issues of organization of accounting and analytical process at the enterprises of the agro-industrial complex of Ukraine]. Vinnytsia: PP Baliuk [in Ukranian].

2. Biudzhetnyi kodeks Ukrainy: nakaz vid 08.07.2010 № 2456-VI [Budget Code of Ukraine: order of 08.07.2010 № 2456-VI]. (2010 July 8). (Redaktsiia stanom na 01.01.2021). Retrieved from: https://zakon.rada.gov.ua/laws/show [in Ukranian].

3. Honcharuk, I.V. (2020). Formuvannia enerhetychnoi nezalezhnosti yak osnovy staloho rozvytku ahropromyslovoho kompleksu [Formation of energy independence as a basis for sustainable development of the agro-industrial complex]. Ahrosvit-Agroworld, 19-20, 38-46 [in Ukranian].

3. Hutsalenko, L.V., \& Zdyrko, N.H. (2014). Oblikovo-kontrolne zabezpechennia priamoi derzhavnoi pidtrymky fermerskykh hospodarstv [Accounting and control support of direct state support of farms]. Vinnytsia: «TD «Edelveis i K» [in Ukranian].

4. Demianenko, M.Ia., Sabluk, P.T., Skupyi, V.M. et. al. (2011). Derzhavna polityka finansovoi pidtrymky rozvytku ahrarnoho sektoru APK [State policy of financial support for the development of the agricultural sector of agriculture]. Kyiv: IAE [in Ukranian].

5. Dibrova, A.D. (2008). Derzhavne rehuliuvannia silskohospodarskoho vyrobnytstva: teoriia, metodolohiia, praktyka [State regulation of agricultural production: theory, methodology, practice]. Kyiv: Format [in Ukranian].

7. Informatsiino-analitychnyi portal APK Ukrainy [Information and analytical portal of the AIC of Ukraine]. agro.me.gov.ua. Retrieved from: https://agro.me.gov.ua/ua [in Ukranian].

8. Kalashnikova, T.V. (2014). Udoskonalennia derzhavnoi pidtrymky ahrarnykh pidpryiemstv Ukrainy $v$ umovakh hlobalizatsii [Improving state support for agricultural enterprises of Ukraine in the context of globalization]. Kharkiv: «Vlavke» [in Ukranian].

9. Kaletnik, H.M., \& Koziar, N.O. (2020). Stratehichni pidkhody do investuvannia ahrarnoho sektoru Ukrainy $\mathrm{v}$ suchasnykh umovakh rozvytku APK 
[Strategic approaches to investing in the agricultural sector of Ukraine in modern conditions of agro-industrial complex development]. Ekonomika APK - Economics of agro-industrial complex, 12 (314), 81-89 [in Ukranian].

10. Kaletnik, H.M. (2015). Stratehiko-instytutsiini zasady efektyvnosti vykorystannia potentsialu ahrarnoho sektoru ekonomiky [Strategic and institutional principles of effective use of the potential of the agricultural sector of the economy]. Ekonomika, finansy, menedzhment: aktualni pytannia nauky i praktyky - Economy, finances, management: topical issues of science and practice activity, 1, 3-15 [in Ukranian].

11. Koval, N.I., \& Radchenko, O.D. (2019). Determinanty stanu finansovykh resursiv malykh ahrarnykh pidpryiemstv [Determinants of the state of financial resources of small agricultural enterprises]. Ekonomika, finansy, menedzhment: aktualni pytannia nauky i praktyky - Economy, finances, management: topical issues of science and practice activity, 3, 100-116 [in Ukranian].

12. Koval, N.I., \& Radchenko, O.D. (2013). Oblikove zabezpechennia upravlinnia finansovoiu diialnistiu ahrarnykh pidpryiemstv [Accounting support for the management of financial activities of agricultural enterprises]. Vinnytsia: «TD «Edelveis i K» [in Ukranian].

13. Maistro, S.V. (2009). Natsionalnyi ahrarnyi rynok v umovakh hlobalizatsii: mekhanizm derzhavnoho rehuliuvannia [The national agrarian market in the conditions of globalization: the mechanism of state regulation]. Kharkiv: NADU [in Ukranian].

14. Kvasha, S.M., Vytvytska, O.D., \& Nakonechna, K.V. Mekhanizm derzhavnoi pidtrymky silskohospodarskoho vyrobnytstva ta shliakhy yoho udoskonalennia [The mechanism of state support for agricultural production and ways to improve it]. Kyiv: IAE [in Ukranian].

15. Mishchenko, D.A. (2015). Udoskonalennia systemy derzhavnoi finansovoi pidtrymky silskoho hospodarstva Ukrainy [Improving the system of state financial support for agriculture in Ukraine]. Ahrosvit - Agroworld, 18, 36-40 [in Ukranian].

16. Zhuk, V., Herasymuk, I., Radchenko, O., Metelytsia, V. (2007). Oblik derzhavnoi pidtrymky ahropromyslovoho vyrobnytstva [Accounting for state support of agro-industrial production]. Kyiv: Iur-Ahro-Vesta [in Ukranian].

17. Pro zatverdzhennia Poriadku vykorystannia koshtiv, peredbachenykh u derzhavnomu biudzheti dlia finansovoi pidtrymky silhosptovarovyrobnykiv: postanova KMU vid 08 lutoho 2017, № 77 [On approval of the Procedure for the use of funds provided in the state budget for financial support of agricultural producers: Resolution of the Cabinet of Ministers of 08 February 2017 № 77]. (2017, 8 February). zakon.rada.gov.ua.

Retrieved

from: https://zakon.rada.gov.ua/laws/show/130-2017 [in Ukranian].

18. Pro vnesennia zmin do punktu 3 Poriadku vykorystannia koshtiv, peredbachenykh u derzhavnomu biudzheti dlia finansovoi pidtrymky silhosptovarovyrobnykiv. Postanova KMU vid 7 kvitnia 2021, № 315 [On amendments to paragraph 3 of the Procedure for the use of funds provided in the state budget for financial support of agricultural producers. Resolution of the Cabinet of Ministers of April 7, 2021 № 315]. (2021, 7 April). zakon.rada.gov.ua. 
Retrieved from: https://zakon.rada.gov.ua/laws/show/315-2021 [in Ukranian].

19. Pro zatverdzhennia Poriadku vykorystannia koshtiv, peredbachenykh u derzhavnomu biudzheti dlia nadannia finansovoi pidtrymky rozvytku fermerskykh hospodarstv. Postanova KMU vid 7 liutoho 2018, № 106 [On approval of the Procedure for the use of funds provided in the state budget for the provision of financial support for the development of farms. Resolution of the Cabinet of Ministers of February 7, 2018 № 106]. (2018, 7 February). zakon.rada.gov.ua. Retrieved from: https://zakon.rada.gov.ua/laws/show/106-2018 [in Ukranian].

20. Radchenko, O.D., \& Tulush, L.D. (2012). Stratehichni napriamy biudzhetnoho rehuliuvannia rozvytku ahropromyslovoho vyrobnytstva [Strategic directions of budget regulation of agro-industrial production development]. Ekonomika APK - Economics of agro-industrial complex, 10, 81-90 [in Ukranian].

21. Semenyshyna, N.V., \& Radchenko, O.D. (2011). Instytutsii sfery obliku biudzhetnoho finansuvannia silskoho hospodarstva [Institutions of the sphere of accounting of budgetary financing of agriculture]. Zbirnyk naukovykh prats KNEU Collection of scientific works of KNEU, 1, 447-485 [in Ukranian].

22. Pravdiuk, N.L., Mulyk, T.O., \& Mulyk, Ya.I. (2018). Upravlinnia finansovoiu bezpekoiu pidpryiemstv: oblikovo-analitychnyi aspect [Management of financial security of enterprises: accounting and analytical aspect]. Kyiv: «Tsentr uchbovoi literatury» [in Ukranian].

23. Radchenko, O., Tsvihun, I., Yasinetska, I., \& Budniak, L. (2020). Financial resource balance of the agricultural sector: case of Ukraine. Independent Journal of Management \& Production, 11, 8, 615-625 [in English].

24. European Plan for Ukraine. g8fiplkplyr33r3krz5b97d1-wpengine.netdnassl.com. Retrieved from: https://g8fip1kplyr33r3krz5b97d1-wpengine.netdnassl.com/wp-content/uploads/2017/11/Presentation-EuropeanPlan Ukraineupdate.pdf [in English].

25. Dani Derzhavnoi kaznacheiskoi sluzhby Ukrainy [Data from the State Treasury Service of Ukraine]. treasury.gov. Retrieved from: https://www.treasury.gov.ua/ua [in Ukranian].

\section{Відомості про авторів}

КОВАЛЬ Наталія Іванівна - кандидат економічних наук, доцент кафедри обліку та оподаткування в галузях економіки, Вінницький національний аграрний університет (21008, м. Вінниця, вул. Сонячна, 3, e-mail: natkov@i.ua).

РАДЧЕНКО Оксана Дмитрівна - кандидат економічних наук, провідний науковий співробітник відділу фінансово-кредитної та податкової політики ННЦ «Інститут аграрної економіки» (03127, м Київ, вул. Героїв Оборони, 10, e-mail: oxanarad@ukr.net).

ІЩЕНКО Яна Петрівна - кандидат економічних наук, доцент кафедри обліку та оподаткування в галузях економіки, Вінницький національний аграрний університет (21008, м. Вінниця, вул. Сонячна, 3, e-mail: jana_2006@ukr.net).

KOVAL Natalia - Candidate of Economic Sciences, Associate Professor of 
the Departments of Account and Taxation in the Fields of the Economy, Vinnytsia National Agrarian University (21008, Vinnytsia, 3, Soniachna Str., e-mail: Natkov@i.ua).

RADCHENKO Oksana - Candidate of Economic Sciences, Leading Researcher of Financial, Credit and Tax Policy Department NSC «Institute of Agrarian Economics» (03127, Kyiv, 10, Heroes of Defense Str., e-mail: oxanarad@ukr.net).

ISHCHENKO Yana - Candidate of Economic Sciences, Associate Professor of the Departments of Account and Taxation in the Fields of the Economy, Vinnytsia National Agrarian University (21008, Vinnytsia, 3, Soniachna Str., e-mail: jana_2006@ukr.net).

КОВАЛЬ Наталия Ивановна - кандидат экономических наук, доцент кафедры учета и налогообложения в отраслях экономики, Винницкий национальный аграрный университет $(21008$, г. Винница, ул. Солнечна, 3 , e-mail: Natkov@i.ua).

РАДЧЕНКО Оксана Дмитриевна - кандидат экономических наук, ведущий научный сотрудник отдела финансово-кредитной и налоговой политики ННЦ «Институт аграрной экономики» (03127, г. Киев, ул. Героев Обороны, 10, e-mail: oxanarad@ukr.net).

ИЩЕНКО Яна Петровна - кандидат экономических наук, доцент кафедры учета и налогообложения в отраслях экономики, Винницкий национальный аграрный университет $(21008$, г. Винница, ул. Солнечная, 3, e-mail: jana_2006@ukr.net).

УДК 336.77:338.432

DOI: 10.37128/2411-4413-2021-2-9

ТЕОРЕТИЧНІ

АСПЕКТИ СУТНОСТІ

ТА ОСОБЛИВОСТЕЙ

КРЕДИТНИХ

ВІДНОСИН У

АГРАРНОМУ СЕКТОРI ЕКОНОМІКИ

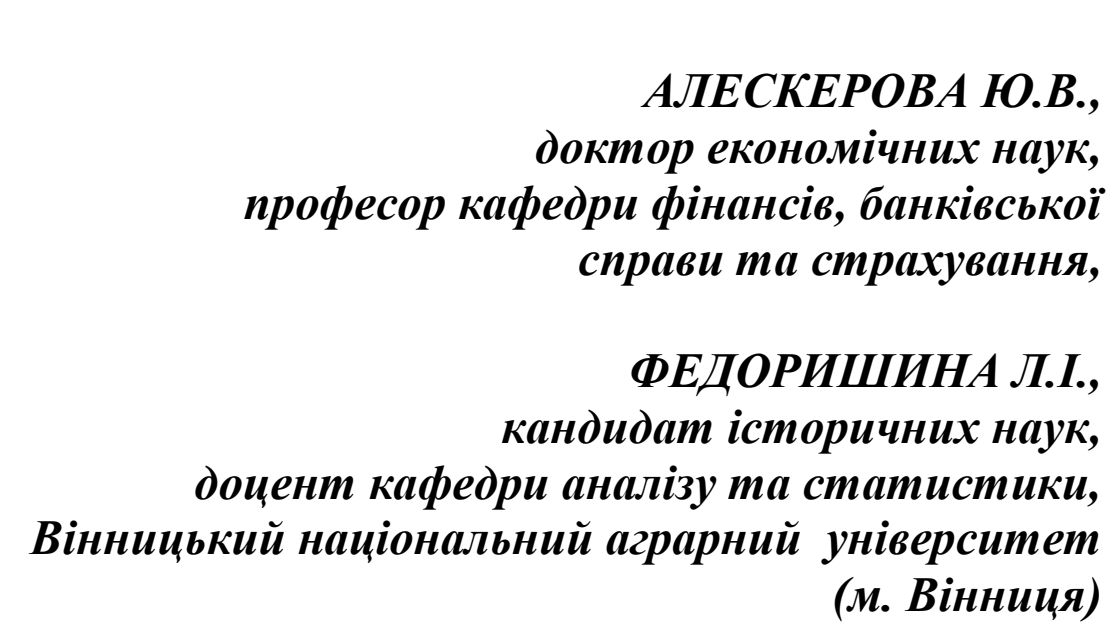

У статті деталізовано $і$ розкрито сутність поняття «кредит», досліджено еволюиійні передумови виникнення та становлення категоріального апарату кредитування, визначено характерні риси кредиту, які висвітлені представниками різних теорій. Систематизовано етапи розвитку кредитних відносин у суспільстві. Висвітлено етапи розвитку кредитних відносин, принщипи, функиії та особливості кредитування підприємств аграрного сектору економіки.

Досліджено еволючійні аспекти кредиту, як економічної категорії з позиції капіталотворчої теорії та теорії кредитного регулювання. 